Article

\title{
Enhancement of Alkaline Protease Activity and Stability via Covalent Immobilization onto Hollow Core-Mesoporous Shell Silica Nanospheres
}

\author{
Abdelnasser Salah Shebl Ibrahim 1,2,*, Ali A. Al-Salamah ${ }^{1}$, Ahmed M. El-Toni ${ }^{3,4}$, \\ Khalid S. Almaary ${ }^{1}$, Mohamed A. El-Tayeb ${ }^{1}$, Yahya B. Elbadawi ${ }^{1}$ and Garabed Antranikian ${ }^{5}$ \\ 1 Department of Botany and Microbiology, College of Science, King Saud University, Riyadh 11451, \\ Saudi Arabia; aaasalah98@yahoo.com (A.A.A.-S.); kalmaary@ksu.edu.sa (K.S.A.); \\ mohamedmicro32@yahoo.com (M.A.E.-T.); alzeeem95@yahoo.com (Y.B.E.) \\ 2 Department of Chemistry of Natural and Microbial Products, Pharmaceutical Industries Research Division, \\ National Research Center, El-Buhouth St., Dokki, Cairo 12311, Egypt \\ 3 King Abdullah Institute for Nanotechnology, King Saud University, Riyadh 11451, Saudi Arabia; \\ aamohammad@ksu.edu.sa \\ 4 Central Metallurgical Research and Development Institute, Helwan, Cairo 11421, Egypt \\ 5 Institute of Technical Microbiology, Hamburg University of Technology, Hamburg 21073, Germany; \\ antranikian@tuhh.de \\ * Corresponding: ashebl@ksu.edu.sa; Tel.: +966-5973-5914
}

Academic Editor: Vladimír Kř̀en

Received: 8 December 2015; Accepted: 25 January 2016; Published: 29 January 2016

\begin{abstract}
The stability and reusability of soluble enzymes are of major concerns, which limit their industrial applications. Herein, alkaline protease from Bacillus sp. NPST-AK15 was immobilized onto hollow core-mesoporous shell silica (HCMSS) nanospheres. Subsequently, the properties of immobilized proteases were evaluated. Non-, ethane- and amino-functionalized HCMSS nanospheres were synthesized and characterized. NPST-AK15 was immobilized onto the synthesized nano-supports by physical and covalent immobilization approaches. However, protease immobilization by covalent attachment onto the activated HCMSS- $\mathrm{NH}_{2}$ nanospheres showed highest immobilization yield $(75.6 \%)$ and loading capacity $(88.1 \mu \mathrm{g}$ protein $/ \mathrm{mg}$ carrier) and was applied in the further studies. In comparison to free enzyme, the covalently immobilized protease exhibited a slight shift in the optimal pH from 10.5 to 11.0, respectively. The optimum temperature for catalytic activity of both free and immobilized enzyme was seen at $60^{\circ} \mathrm{C}$. However, while the free enzyme was completely inactivated when treated at $60^{\circ} \mathrm{C}$ for $1 \mathrm{~h}$ the immobilized enzyme still retained $63.6 \%$ of its initial activity. The immobilized protease showed higher $V_{\max }, k_{c a t}$ and $k_{c a t} / K_{m}$, than soluble enzyme by 1.6-, 1.6- and 2.4-fold, respectively. In addition, the immobilized protease affinity to the substrate increased by about 1.5 -fold. Furthermore, the enzyme stability in various organic solvents was significantly enhanced upon immobilization. Interestingly, the immobilized enzyme exhibited much higher stability in several commercial detergents including OMO, Tide, Ariel, Bonux and Xra by up to 5.2-fold. Finally, the immobilized protease maintained significant catalytic efficiency for twelve consecutive reaction cycles. These results suggest the effectiveness of the developed nanobiocatalyst as a candidate for detergent formulation and peptide synthesis in non-aqueous media.
\end{abstract}

Keywords: alkaline protease; immobilization; hollow core-mesoporous shell silica nanospheres; nanotechnology; alkaliphiles; detergents 


\section{Introduction}

Currently enzymes are widely used as alternative of chemical catalysts in various industries; and playing a significant role in development of ecofriendly technology, owing to their unique properties including high specificity, mild reaction conditions, low toxicity and selectivity [1,2]. Proteases (EC 3.4.21-24 and 99) represent one of the most important classes of industrial enzymes, that account for up to $60 \%$ of the total enzyme sales worldwide [3]. Proteases have long been used to catalyze the hydrolysis of various proteins in aqueous solutions, in addition to peptides synthesis in non-aqueous media [4]. Alkaline proteases, accounting alone for approximately $40 \%$ of the total global enzymes market, proved particularly suitable for several industrial applications such as detergent, pharmaceutical, leather, dairy, silk, soy processing, brewery, meat tenderization, and waste management $[5,6]$. This is attributed mainly to significant activity and operational stability under harsh operational conditions, including high $\mathrm{pH}$ and temperature and in the presence of surfactants $[4,7,8]$.

Enzyme immobilization on solid supports represents an efficient approach to improve enzyme stability as well as offering unique merits over the soluble biocatalyst such as operational stability, reusability of the enzyme, bioprocess control, and simplifying product separation $[9,10]$. Recent advance in nanotechnology have provided diverse nanostructured materials that are more effective for biocatalyst immobilization. It was shown that nanostructured materials can enhance the efficiency of the immobilized enzymes by providing the maximum limits in balancing the key parameters that determine the effectiveness of immobilized enzymes such as large surface area, minimum mass transfer resistance, and high enzyme loading [11]. However, selection of suitable enzyme carriers and the applied immobilization approach is of significant importance for successful immobilization processes. Among inorganic materials, mesoporous silica nanoparticles (MPS) are of special interest for enzyme immobilization technology, which is characterized by large surface areas, easily functionalizable surfaces and confined nanospace for enzyme inclusion, in addition to high biocompatibility and low toxicity [12]. MPS nanoparticles with different morphologies have been fabricated and applied in enzyme immobilization [13,14]. However, hollow mesoporous silica nanoparticles are characterized by several unique features that make them promising candidates for biocatalyst immobilization such as inner voids suitable for inclusion of proteins with various sizes, having surfaces (inner and outer) that can be easily chemically modified and showing high diffusion rate within the mesostructure of the silica shells [15].

In the present study, a recently characterized alkaline protease from alkaliphilic Bacillus sp. NPST-AK15 [16,17] was immobilized onto hollow core-mesoporous shell silica (HCMSS) nanospheres by two approaches including covalent and physical immobilization. Subsequently, the properties of immobilized protease were investigated.

\section{Results and Discussion}

\subsection{Fabrication and Characterization of Hollow Core-Mesoporous Shell Silica Nanospheres}

Hollow core-mesoporous shell silica (HCMSS) nanospheres were synthesized by anionic surfactant through a soft-templating route assisted by ultrasonic waves. In this route, negatively charged silica nuclei are reacted with anionic surfactant through a co-structure directing agent (3-aminopropyltrimethoxysilane (APMS)) to produce mesoporous silica nanospheres. On the other hand, hollow core structures are obtained through assembling of the anionic surfactant micelles on the bubbles created in the solution by ultrasonic waves and then the silica nuclei are precipitated to form a hollow core structure. The template was removed using solvent extraction to maintain the functionalization of HCMSS spheres with amino groups. Figure 1 shows amino functionalized hollow core-mesoporous shell silica spheres (HCMSS- $\mathrm{NH}_{2}$ ) using anionic surfactant. $\mathrm{HCMSS}-\mathrm{NH}_{2}$ possessed spheres with sizes ranged from 200-300 nm while the shell thickness was around $30 \mathrm{~nm}$. The non-functionalized hollow core-mesoporous shell spheres (HCMSS-non) were produced by calcination at $550{ }^{\circ} \mathrm{C}$ of amino-functionalized ones. Ethane functionalization was conducted on 
HCMSS-non spheres through post-synthesis approach. Both calcination and ethane functionalization steps did not affect the morphology of hollow core nanostrucures.

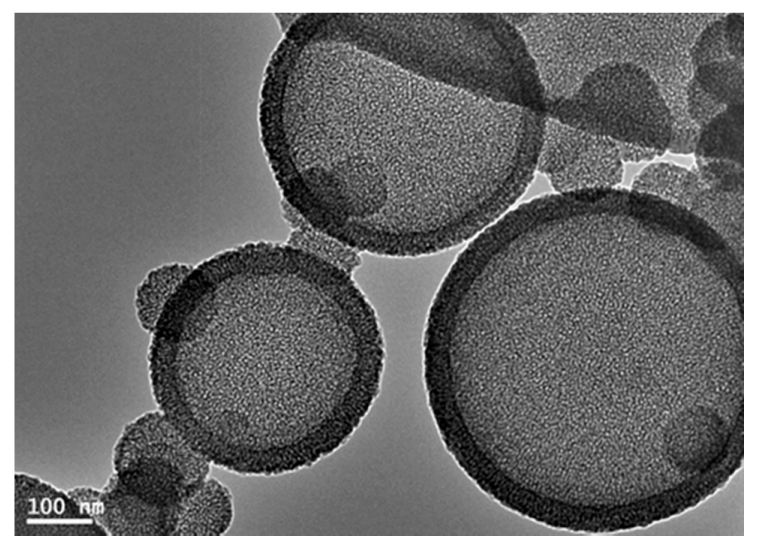

Figure 1. TEM images of amino-functionalized hollow core-mesoporous silica $\left(\mathrm{HCMSS}-\mathrm{NH}_{2}\right)$ nanospheres prepared by anionic surfactant.

The typical nitrogen adsorption/desorption isotherms for the hollow core-mesoporous shell silica sphere samples with various functionalities are presented in Figure 2A. The isotherms showed the type IV curves that depicted the uniform mesoporous feature of hollow core-mesoporous shell silica nanospheres [18]. The Brunauer-Emmett-Teller (BET) surface area and total pore volume of HCMSS- $\mathrm{NH}_{2}$ nanospheres were $307.13 \mathrm{~cm}^{2} \cdot \mathrm{g}^{-1}$ and $0.576 \mathrm{cc} \cdot \mathrm{g}^{-1}$, respectively. Removal of amino groups by calcination resulted in increment of surface area to $394.27 \mathrm{~cm}^{2} \cdot \mathrm{g}^{-1}$ while the pore volume was almost closer to amino-functionalized sample $\left(0.545 \mathrm{cc} \cdot \mathrm{g}^{-1}\right)$. These results are expected because the calcination would remove the amino groups which lead to improvement of surface area of hollow core nanostructures. Ethane functionalization through post-synthesis approach resulted in decrease of both surface area and pore volume to $270.42 \mathrm{~cm}^{2} \cdot \mathrm{g}^{-1}$ and $0.438 \mathrm{cc} \cdot \mathrm{g}^{-1}$, respectively. This is due to blockage of surface sites and mesopores with ethane groups. Pore size distribution for the hollow core-mesoporous shell silica sphere samples with different functionalities are illustrated in Figure 2B. All samples showed an identical pore size distribution profile, which centered around $3.6 \mathrm{~nm}$. In that regard, reduction of the total pore volume upon functionalization without reduction of the mesopores size suggested that the ethane groups were concentrated on the bottom or the entrance of mesopores rather than homogenously distributed all over the channels and therefore the pore volume was reduced while pore size was not affected.
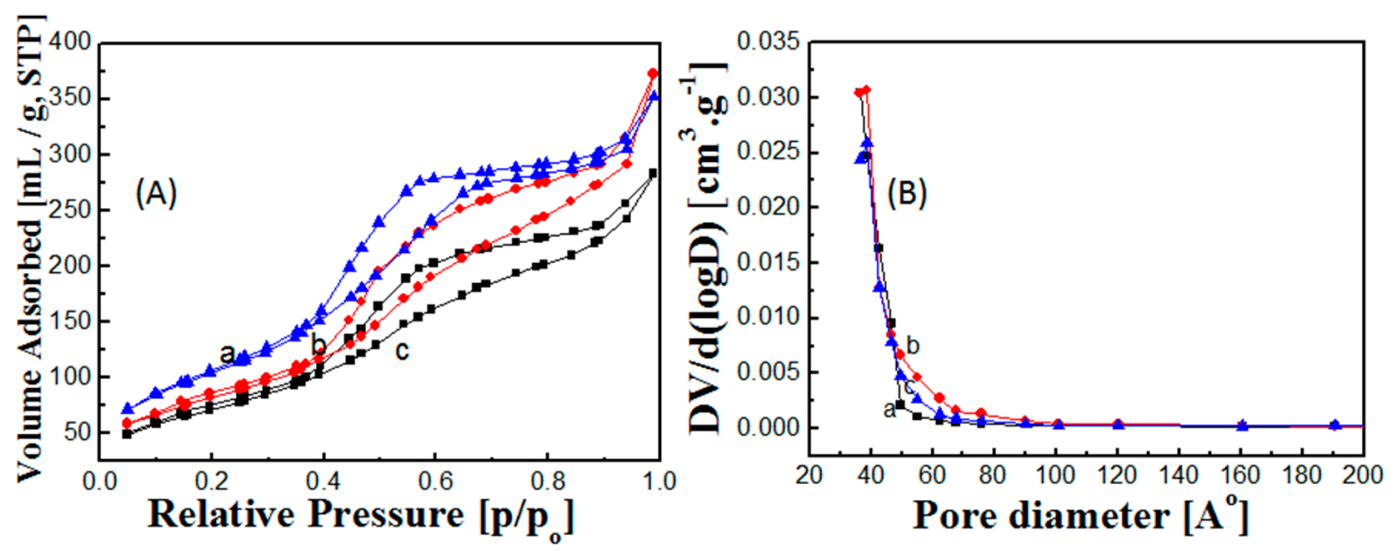

Figure 2. (A) $\mathrm{N}_{2}$ adsorption-desorption isotherms and (B) pore size distribution of (a) non-functionalized, (b) amino-functionalized and (c) ethane-functionalized of hollow core-mesoporous shell silica nanospheres. 
FT-IR measurements were made and demonstrated that different functional groups existed in the hollow structure as shown in Figure 3. Non-functionalized hollow silica spheres (Figure 3a) showed main $\mathrm{Si}-\mathrm{O}$ peak which is characteristic for silica at $1050-1250 \mathrm{~cm}^{-1}$. Amino functionalization of hollow nanospheres (Figure 3b) through using APMS can be confirmed from the presence of a N-H peak at $1637 \mathrm{~cm}^{-1}$ [19]. Functionalization of hollow silica spheres with ethane group $\left(\mathrm{CH}_{2}-\mathrm{CH}_{2}\right)$ was shown by the appearance of a peak at $1415 \mathrm{~cm}^{-1}$ together with a $\mathrm{C}-\mathrm{H}$ stretching vibrations peak at $2862 \mathrm{~cm}^{-1}$ which confirmed the presence of hydrophobic ethane groups within mesochannels as shown in Figure 3c [20]. However, the appearance of an N-H peak at $1637 \mathrm{~cm}^{-1}$ and $\mathrm{C}-\mathrm{H}$ at $2862 \mathrm{~cm}^{-1}$ (from APMS functionalization) as seen in Figure 3a (non-functionalized) could indicate the presence of some residual amino and ethoxy groups from APMS functionlization that were not removed completely during the calcination process. However, weak intensity of $\mathrm{N}-\mathrm{H}$ and $\mathrm{C}-\mathrm{H}$ peaks in Figure 3a suggest low content of these functional moieties due to the effect of heat treatment.
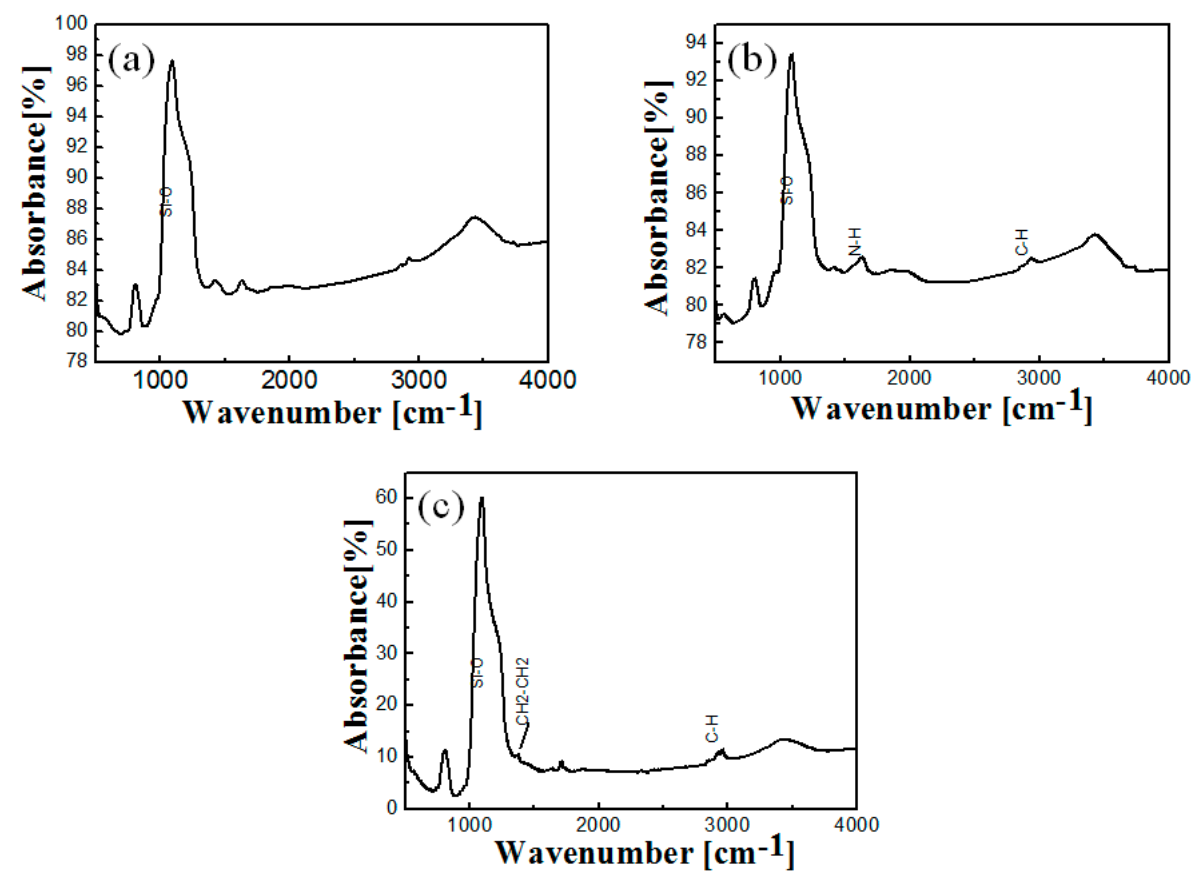

Figure 3. FT-IR spectra of (a) non-functionalized; (b) amino-functionalized and (c) ethane-functionalized hollow core-mesoporous shell silica nanospheres.

\subsection{Protease Immobilization}

Purification of alkaline protease from alkaliphilic Bacillus sp. NPST-AK15 culture supernatant was carried out through a combination of ammonium sulfate precipitation and anion exchange chromatography as we described in a previous work [17]. The purified enzyme was immobilized onto the synthesized HCMSS nanospheres by covalent attachment and physical adsorption. Three samples were used for physical immobilization that included HCMSS-non, HCMSS- $\mathrm{C}_{2} \mathrm{H}_{5}$, and HCMSS- $\mathrm{NH}_{2}$. For covalent immobilization, the amino functionalized hollow core-mesoporous silica (HCMSS- $\mathrm{NH}_{2}$ ) nanospheres were first activated by glutaraldehyde as a bifunctional cross linking agent prior to protease conjugation. The crosslinking of the matrix with glutaraldehyde takes place in two steps in which the free amino groups within the mesopores and hollow core of $\mathrm{HCMSS}-\mathrm{NH}_{2}$ nanospheres react with terminal aldehyde groups of glutaraldehyde molecules to form a Schiff-base linkage and then the free amino groups in protease molecules condense with the other free terminal aldehyde groups of glutaraldehyde to form a second Schiff-base bonding [21]. The results presented in Table 1 revealed that NPST-AK15 protease was immobilized successfully onto different hollow core-mesoporous shell silica (HCMSS) nanospheres either by covalent or physical immobilization. 
However, immobilization of NPST-AK15 protease by covalent conjugation was more effective exhibiting much higher immobilization yield $(75.6 \%)$ and loading efficiency $(73.6 \%)$ relative to physical immobilization, which can be attributed to the strong covalent bonds formed between the protease molecules and the activated HCMSS- $\mathrm{NH}_{2}$ nanospheres through the cross linking agent. On the other hand, immobilization of NPST-AK15 protease by physical adsorption gave low immobilization yield and loading efficiency in all tested supports, suggesting weak electrostatic and hydrophobic interaction between the NPST-AK15 protease molecules and HCMSS nanospheres [22].

Table 1. Immobilization of NPST-AK15 alkaline protease onto hollow core-mesoporous shell silica (HCMSS) nanospheres. The standard deviations were in the range of $1 \%-3 \%$.

\begin{tabular}{|c|c|c|c|c|}
\hline Matrix & $\begin{array}{l}\text { Immobilization } \\
\text { Method }\end{array}$ & $\begin{array}{l}\text { Immobilization } \\
\text { Yield * }(\%)\end{array}$ & $\begin{array}{c}\text { Activity } \\
\text { Yield ** (\%) }\end{array}$ & $\begin{array}{l}\text { Loading Efficiency } \\
* * *(\%)\end{array}$ \\
\hline HCMSS-non & Physical adsorption & 44.6 & 40.0 & 41.2 \\
\hline HCMSS-NH 2 & Physical adsorption & 47.3 & 42.3 & 44.7 \\
\hline $\mathrm{HCMSS}-\mathrm{C}_{2} \mathrm{H}_{5}$ & Physical adsorption & 19.3 & 16.3 & 18.0 \\
\hline HCMSS-NH & Covalent attachment & 75.6 & 72.2 & 73.6 \\
\hline
\end{tabular}

* Immobilization yield $(\%)=[(\mathrm{A}-\mathrm{B}) / \mathrm{A}] \times 100$, where $\mathrm{A}$ is the total activity of the enzyme added in the initial immobilization solution and B is the activity of the unbound protease; ** Activity yield $=(C / A) \times 100$, where $A$ is the total activity of the enzyme added in the initial immobilization solution, and $C$ is activity of the immobilization protease; ${ }^{* *}$ Loading efficiency $=\left[\left(\mathrm{P}_{\mathrm{i}}-\mathrm{P}_{\mathrm{unb}}\right) / \mathrm{P}_{\mathrm{i}}\right] \times 100$, where $\mathrm{P}_{\mathrm{i}}$ and $\mathrm{P}_{\text {unb }}$ are the initial protein subjected to immobilization, and the unbound protein, respectively.

\subsection{FT-IR of Free and Immobilized Protease}

The binding of the NPST-AK15 protease to HCMSS- $\mathrm{NH}_{2}$ was further confirmed by FT-IR analysis. FT-IR spectra for pure free NPST-AK15 protease, $\mathrm{HCMSS}-\mathrm{NH}_{2}$ nanospheres and immobilized enzyme are illustrated in Figure 4. The spectrum of protease (Figure 4a) showed a strong peak at range of $1640-1650 \mathrm{~cm}^{-1}$ which corresponds to the amide I and amide II groups [10]. The strong broad band appearing at $3100-3600 \mathrm{~cm}^{-1}$ can be attributed to $\mathrm{N}-\mathrm{H}$ stretching of protease amides [10]. FT-IR spectrum of HCMSS-NH $\mathrm{NH}_{2}$ nanospheres is shown in Figure $4 \mathrm{~b}$. The strong peak at $1050-1250 \mathrm{~cm}^{-1}$ is attributed to $\mathrm{Si}-\mathrm{O}$ bonding [19]. The amino functionalization of HCMSS spheres was demonstrated from the appearance of an $\mathrm{N}-\mathrm{H}$, peak at $1637 \mathrm{~cm}^{-1}$ as well as $\mathrm{OCH}_{2} \mathrm{CH}_{3}$ and $\mathrm{C}-\mathrm{H}$ stretching vibrations peaks at 2930 and $2862 \mathrm{~cm}^{-1}$, respectively [19]. The FT-IR of the immobilized protease shown in Figure $4 \mathrm{c}$ indicated the presence of a strong peak at $1640-1650 \mathrm{~cm}^{-1}$ for amide, and a broad one at $3100-3600 \mathrm{~cm}^{-1}$ for the $\mathrm{N}-\mathrm{H}$ group of the protease, together with the main peaks of hollow core-mesoporous shell silica spheres as $\mathrm{Si}-\mathrm{O}$ bond at $1050-1250 \mathrm{~cm}^{-1}$. These results demonstrate and confirm successful immobilization of the NPST-AK15 protease onto $\mathrm{HCMSS}-\mathrm{NH}_{2}$ nanospheres.

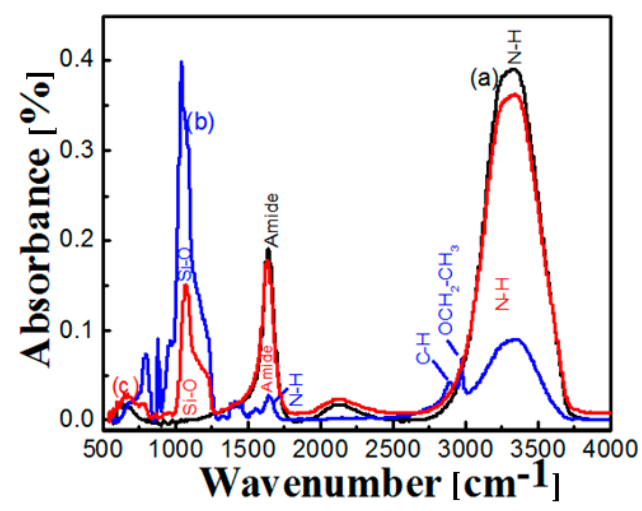

Figure 4. FTIR spectra of (a) Free NPST-AK15 protease enzyme (balck); (b) amino-functionalized hollow core-mesoporous silica (HCMSS- $\mathrm{NH}_{2}$ ) nanospheres (blue) and (c) NPST-AK15 protease immobilized onto amino-functionalized hollow core-mesoporous silica (HCMSS- $\mathrm{NH}_{2}$ ) nanospheres (red). 


\subsection{Loading Capacity}

The loading capacity of Ac-HCMSS- $\mathrm{NH}_{2}$ nanospheres was estimated by covalent immobilization of various amounts of NPST-AK15 protease and ranged from 50 to $200 \mu \mathrm{g}$ protein/10 mg nanoparticles. The results shown in Figure 5 indicated that the amount of loaded protease increased with increasing enzyme concentration giving maximum loading of $88.1 \mu \mathrm{g}$ protein $/ \mathrm{mg}$ carrier, and then remained constant. This result shows that Ac-HCMSS- $\mathrm{NH}_{2}-\mathrm{NH}_{2}$ nanospheres have high loading capacity for covalent immobilization of NPST-AK15 protease [23-25], which can be attributed to the high surface area $\left(307.13 \mathrm{~cm}^{2} \cdot \mathrm{g}^{-1}\right)$ and pore volume of the nanoparticles $\left(0.576 \mathrm{cc} \cdot \mathrm{g}^{-1}\right.$, respectively) available for the enzyme conjugation. Furthermore, functionalization of HCMSS nanospheres with amino groups through in situ approach rather than post-synthesis method resulted in integration of a higher density of amino groups available for protease conjugation [26,27]. Thus, a protein loading of $88.1 \mu \mathrm{g}$ protein per mg Ac-HCMSS- $\mathrm{NH}_{2}-\mathrm{NH}_{2}$ nanospheres was used in all subsequent investigations.

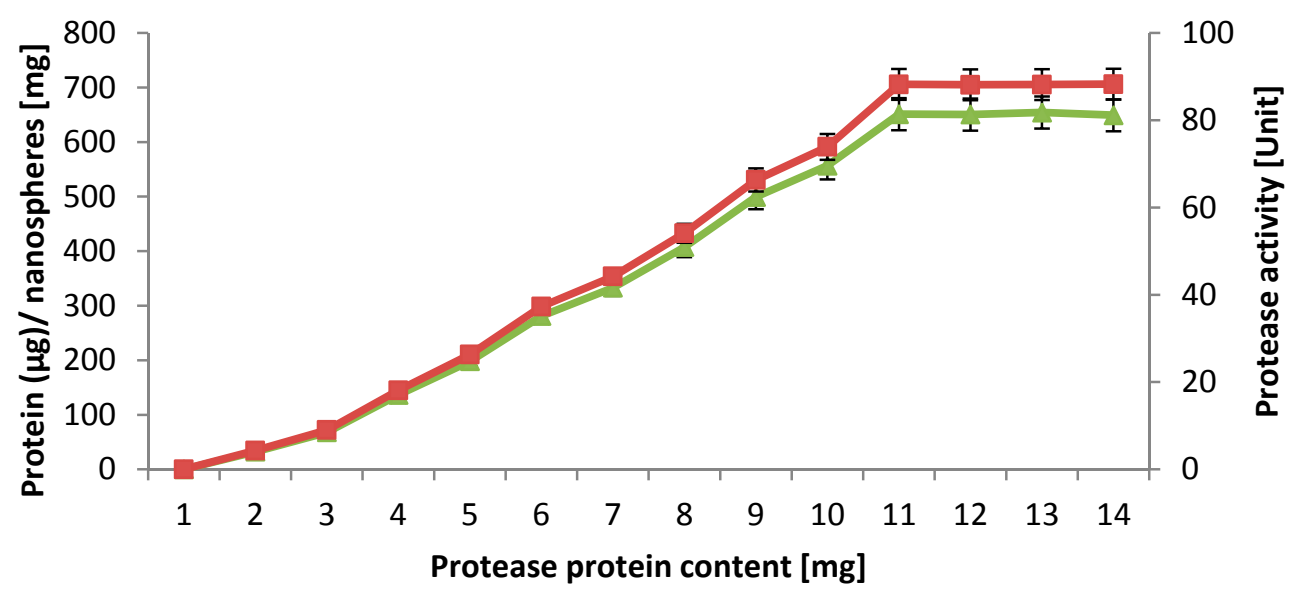

\section{- Protease activity activity $\quad-\mu \mathrm{g}$ protein/mg carrier}

Figure 5. Loading efficiency of hollow core-mesoporous shell silica nanospheres for immobilization of NPST-AK15 protease.

\subsection{Properties of the Immobilized NPST-AK15 Protease}

\subsubsection{Influence of $\mathrm{pH}$ and Temperature}

The results of the effect of $\mathrm{pH}$ on the catalytic activity of both free and immobilized NPST-AK15 protease show that the catalytic activity was increasing as $\mathrm{pH}$ increased, reaching maximum activity at $\mathrm{pH} 10.5$ and 11.0 for soluble and immobilized protease, respectively. Hence, the optimum $\mathrm{pH}$ of alkaline protease immobilized on Ac-HCMSS- $\mathrm{NH}_{2}$ nanospheres was shifted toward the alkaline range by 0.5 units in comparison with the free protease (Figure 6). In addition there was significant increment of the relative activities of the immobilized NPST-AK15 protease at a wide $\mathrm{pH}$ range (pH 5-13) in comparison with free enzyme. The slight shift of optimal $\mathrm{pH}$ value to the alkaline region was probably due to the change of its microenvironment caused by the immobilization of the enzyme on the carrier. An increase of the optimum $\mathrm{pH}$ was observed for the other enzymes immobilized on the solid matrix $[25,28]$. 


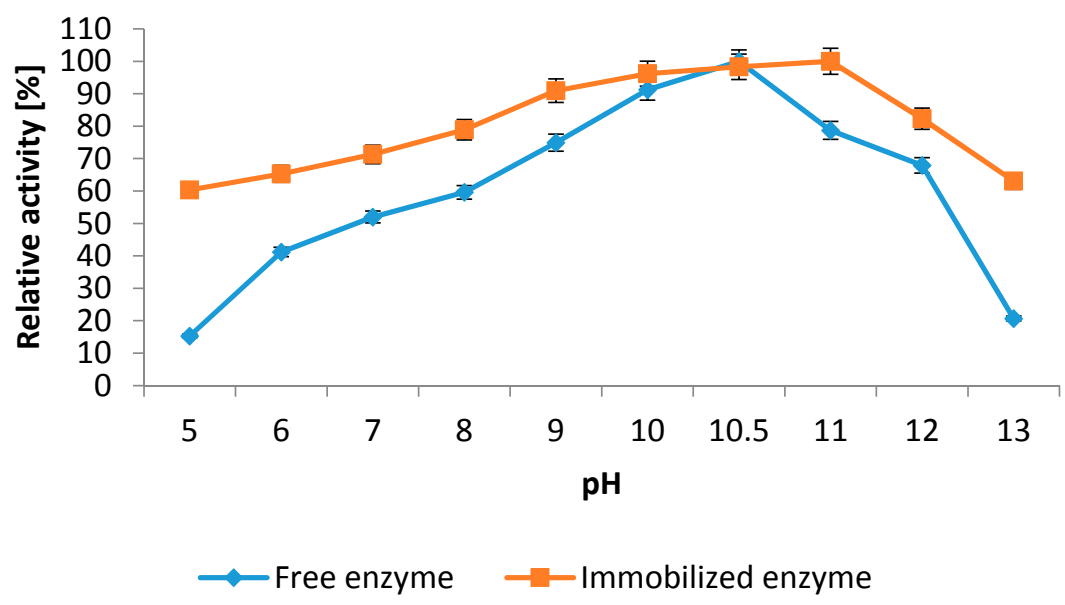

Figure 6. Effect of $\mathrm{pH}$ on the activity of the free and immobilized NPST-AK15 protease. Enzyme activity was measured at $55^{\circ} \mathrm{C}$. The results represent the mean of three separate experiments, and error bars are indicated.

The results of the influence of reaction temperature on the catalytic activity of soluble and immobilized enzyme revealed that the optimum temperature for both free and immobilized enzyme was $60^{\circ} \mathrm{C}$ (Figure 7A). However, the immobilized protease exhibited higher relative activities in comparison with soluble enzyme, especially at high temperatures $\left(65-75^{\circ} \mathrm{C}\right)$. In addition, the thermal stability of free and immobilized protease was investigated at various temperatures $\left(50-60^{\circ} \mathrm{C}\right)$. As shown in Figure 7B the protease immobilized onto the nanosphere showed much better thermal stability compared to free enzyme. After treatment for $1 \mathrm{~h}$ at $55{ }^{\circ} \mathrm{C}$, the immobilized enzyme still retained $73.5 \%$ of its initial activity, while the free protease maintained only $30 \%$. Moreover, while the soluble enzyme was completely inactivated when treated for $1 \mathrm{~h}$ at $60{ }^{\circ} \mathrm{C}$ the immobilized enzyme still retained $63.6 \%$ and $29.3 \%$ of its initial activity, after treatment for 1 and $2 \mathrm{~h}$, respectively. The significant improvement of the immobilized NPST-AK15 protease thermal stability is mostly attributed to multipoint covalent attachment of protease molecules to the matrix that protect the protease tertiary structure and prevent conformation transition of the enzyme upon heating, leading to an improved thermal stability $[9,29]$.

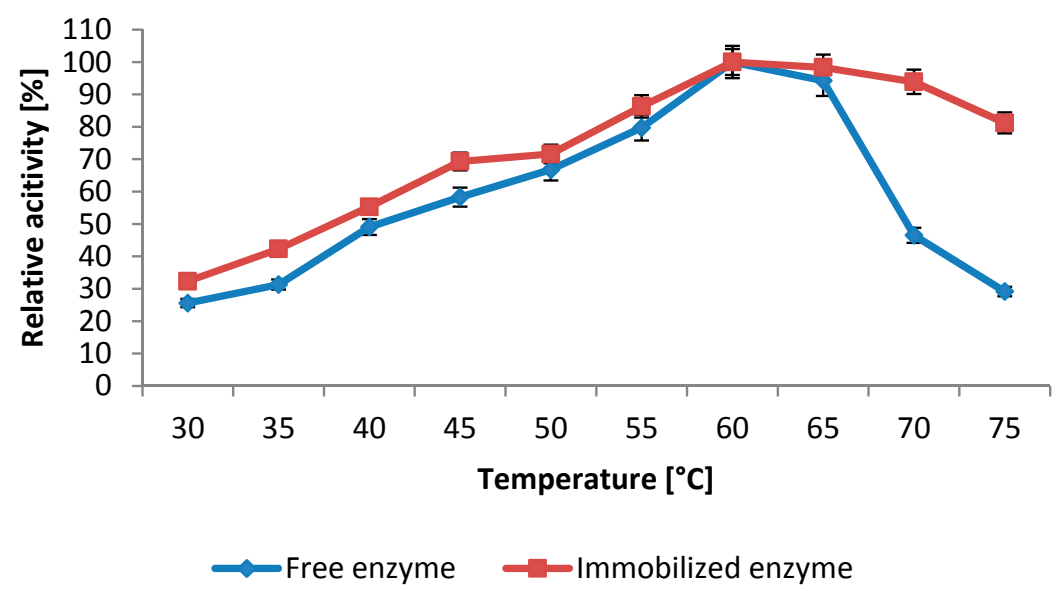

(A)

Figure 7. Cont. 


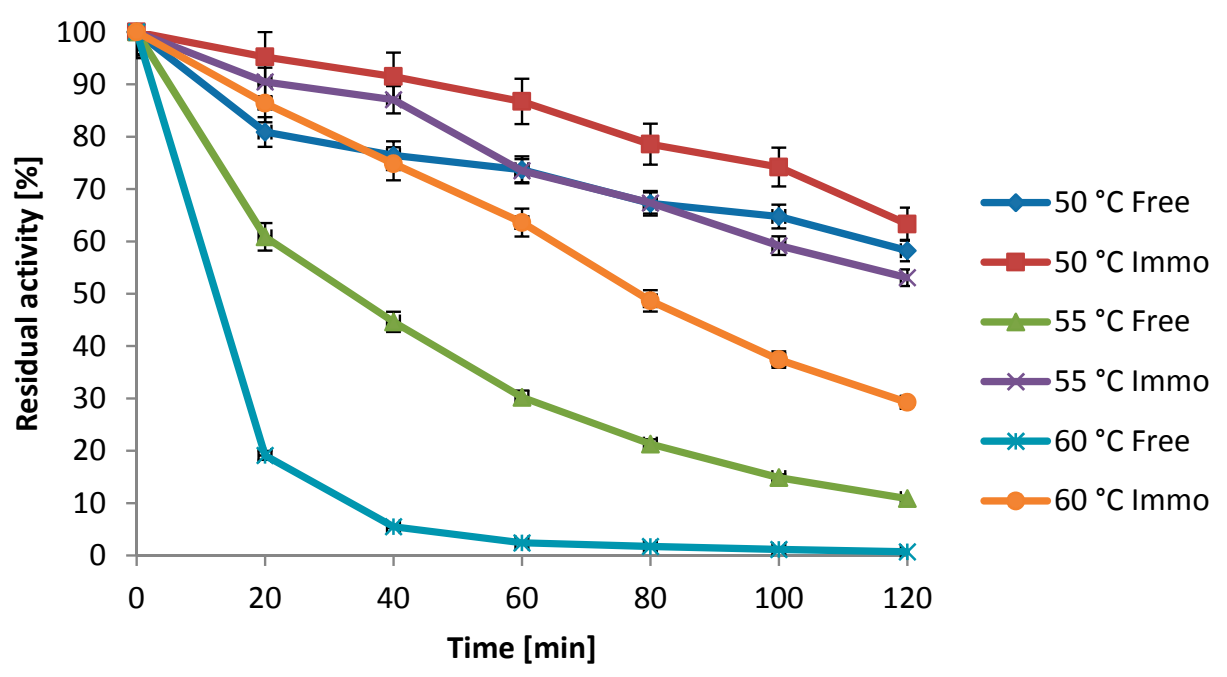

(B)

Figure 7. Effect of temperature on activity (A) and stability (B) of free and immobilized NPST-AK15 protease. Protease activity was measured under the standard assay conditions at various temperatures $\left(30-75^{\circ} \mathrm{C}\right)$ at $\mathrm{pH} 10$. For thermal stability, the enzyme was pre-incubated at different temperatures for $2 \mathrm{~h}$ at $\mathrm{pH}$ 11.0, and the residual enzyme activities were estimated at regular intervals under standard assay conditions. The non-heated enzymes were taken as 100\%. The results represent the mean of three separate experiments, and error bars are indicated.

\subsubsection{Kinetics Studies}

Investigation of the kinetic parameters $\left(K_{\mathrm{m}}\right.$ and $\left.V_{\max }\right)$ is also a critical feature for investigating the effectiveness of an immobilization process. Kinetics parameters of both free and immobilized protease were estimated using Lineweaver-Burk plot by using casein as a substrate at $\mathrm{pH} 11$ and $60{ }^{\circ} \mathrm{C}$. The Michaelis-Menten constant $\left(K_{\mathrm{m}}\right)$ of free and immobilized NPST-AK15 protease were 0.109 and $0.074 \mathrm{mM}$, respectively, which clearly indicated increase of the enzyme affinity toward the substrate by about 1.5-fold up on immobilization onto Ac-HCMSS- $\mathrm{NH}_{2}$ nanospheres (Figure 8; Table 2). This is mostly due to high mass transport of reactants and products within the carrier which is a unique feature of the nanostructure materials. Also the Brownian motion of the nanospheres could result in enhanced substrate-enzyme interaction [30]. This behavior of protease immobilized onto Ac-HCMSS- $\mathrm{NH}_{2}$ nanospheres was superior to several nanoparticles bound to enzyme [25,31]. In addition, the maximum activity $\left(V_{\max }\right)$, enzyme turnover number $\left(k_{\text {cat }}\right)$, and catalytic efficiency $\left(k_{\text {cat }} / K_{\mathrm{m}}\right)$ values of NPST-AK15 protease were increased by about 1.6-, 1.6-, and 2.4-fold, respectively, upon immobilization on to HCMSS- $\mathrm{NH}_{2}$ nanospheres. This may be due to more efficient conformation of immobilized protease within the nanoscale spaces of the hollow nanospheres in respect to free enzyme [28]. The high affinity toward substrate and catalytic activity of NPST-AK15 alkaline protease immobilized onto Ac-HCMSS- $\mathrm{NH}_{2}$ nanospheres indicate the efficiency and effectiveness of applied support and immobilization approach.

Table 2. Kinetic parameters of free and immobilized NPST-AK15 alkaline protease. The standard deviations were in the range of $1.5 \%-3.1 \%$.

\begin{tabular}{ccc}
\hline Kinetic Parameters & Free Protease & Immobilized Protease \\
\hline$K_{\mathrm{m}}(\mathrm{mM})$ & 0.109 & 0.074 \\
$V_{\max }\left(\mu \mathrm{M} \cdot \mathrm{min}^{-1} \cdot \mathrm{mg}^{-1}\right)$ & 41.2 & 66.1 \\
$k_{\mathrm{cat}}\left(\mathrm{s}^{-1}\right)$ & 1156.5 & 1855.4 \\
$k_{\mathrm{cat}} / K_{\mathrm{m}}\left(\mathrm{mM}^{-1} \cdot \mathrm{s}^{-1}\right)$ & $10.6 \times 10^{3}$ & $25.1 \times 10^{3}$ \\
\hline
\end{tabular}




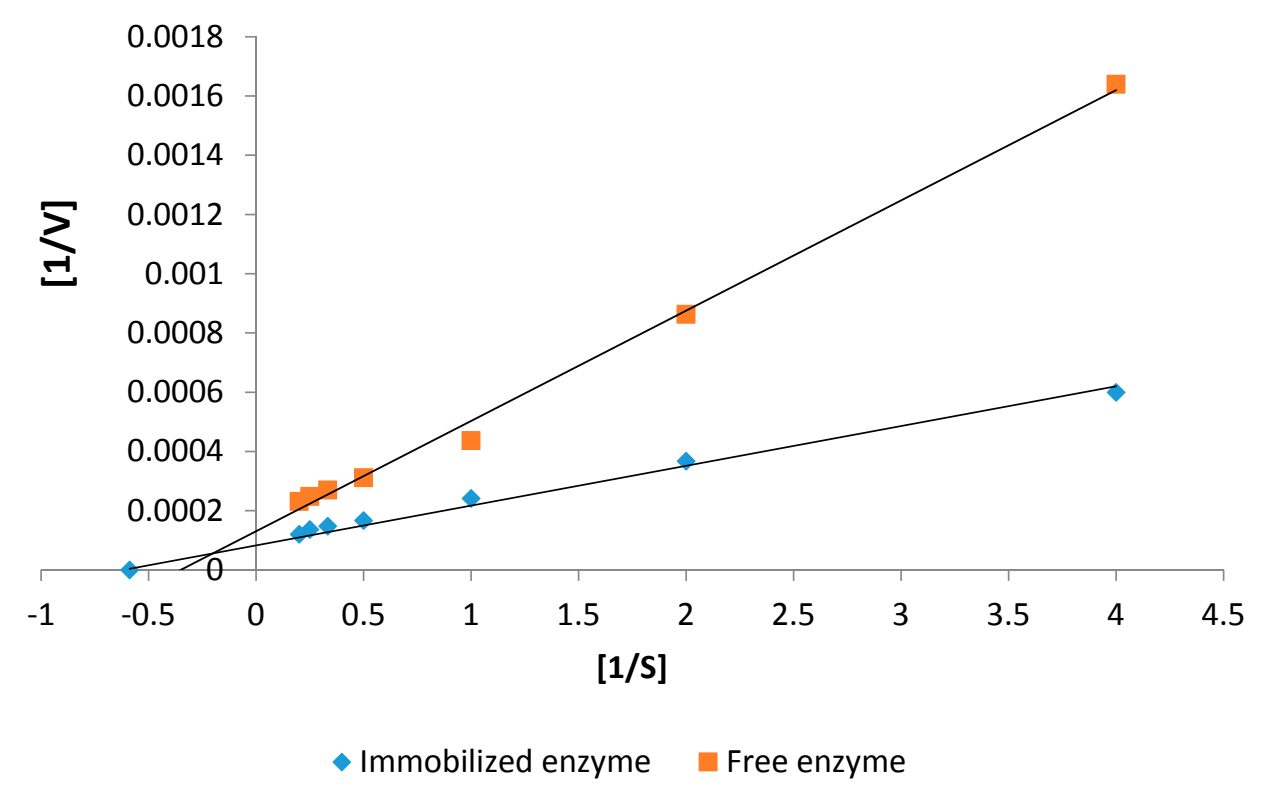

Figure 8. Estimation of kinetic parameters of the free and immobilized NPST-AK15 protease. The enzyme activity was measured at various casein concentrations $(1.0-10.0 \mathrm{mg} / \mathrm{mL})$ at $\mathrm{pH} 11$ and $60{ }^{\circ} \mathrm{C}$. The $K_{\mathrm{m}}$ and $V_{\max }$ values were determined using linearized Lineweaver-Burk plot. S: Substrate concentration; V: Protease specific activity.

\subsubsection{Effect of Inhibitors and Organic Solvents}

The results of the influence of some inhibitors on catalytic activity of free and immobilized NPST-AK15 protease are summarized in Table 3. Phenylmethanesulfonyl fluoride (PMSF) completely inhibited the free protease activity at $5.0 \mathrm{mM}$, suggesting it belongs to serine protease family $[3,17]$. However, the immobilized enzyme retained $86.3 \%$ of its initial activity. In addition, while the free protease lost about $75 \%$ of its initial activity after treatment with $5 \mathrm{mM}$ dithiothreitol (DTT), the immobilized protease maintained $97.5 \%$ at the same conditions. The metal chelating agent, EDTA, caused inhibition of the soluble enzyme to the extent of $60.2 \%$ and $30.5 \%$ at concentrations of 2 and $5.0 \mathrm{mM}$, respectively, suggesting that some metals may play a role in the activity/stability of the enzyme [17], whereas at the same conditions the immobilized protease still retained $95 \%$ and $81.5 \%$ of its initial values, respectively. However, there was no significant difference between the effect of $\beta$-mercaptoethanol ( $\beta$-ME) on free and immobilized NPST-AK15 protease. Protection of protease against such inhibitors upon immobilization onto HCMSS- $\mathrm{NH}_{2}$ nanospheres could be explained in two different ways: (i) In case of allosteric inhibitor in which it interacts with the enzyme at a site other than the catalytic center, it is likely immobilization of the enzyme through that niche leads to distortion of the allosteric site and subsequently causes significant reduction of the inhibition; (ii) Alternatively, if the inhibitor interacts directly with the active center, the process of enzyme immobilization may cause a slight change in the enzyme active site that affects the inhibitor binding to enzyme with less effect on the substrate-enzyme binding especially in the case of high molecular weight substrates [9].

As shown in Figure 9, the stability of the NPST-AK15 protease in various organic solvents was greatly improved upon covalent immobilization onto the Ac-HCMSS- $\mathrm{NH}_{2}$ nanospheres. The results revealed that the stability of the immobilized protease in butanol, isopropanol, chloroform and ethanol was significantly increased by about 2.5-, 2.2-, 1.8- and 1.8-fold respectively, in respect to the free enzyme. In addition, its stability in methanol, toluene, and chloroform was increased by about 1.1-fold. in acetone, toluene, methanol, amyl alcohol and methanol by about 1.7-, 1.5-, 1.4-, and 1.4-fold, in comparison to free enzyme, respectively (Figure 9). The significant enhancement of stability in solvent for NPST-AK15 protease immobilized onto Ac-HCMSS- $\mathrm{NH}_{2}$ nanospheres can be attributed to maintaining the active structural conformation of the enzyme through the multipoint covalent 
attachment to the matrix and entrapment of the protease molecules within the nanospaces of the hollow core of Ac-HCMSS- $\mathrm{NH}_{2}$ nanospheres. Generally, the biotechnological applications of various enzymes could be significantly increased by their utilization in organic media rather than in their natural aqueous conditions. In the last decade the utility of various proteases in organic solvents gained much importance owing to potential applications of proteases in synthesis of ester and peptides in non-aqueous media [32].

Table 3. Influence of some inhibitors on the catalytic activity of free and immobilized NPST-AK15 protease. The standard deviations were in the range of $1.5 \%-3.2 \%$.

\begin{tabular}{cccc}
\hline Inhibitor & Concentration & Free Enzyme & Immobilized Enzyme \\
\hline None & & 100 & 100 \\
\hline \multirow{2}{*}{$\beta$-mercaptoethanol } & 1 & $94.3 \pm 2.4$ & 94.0 \\
& 5 & $88.0 \pm 2.2$ & 89.0 \\
\hline \multirow{2}{*}{ PMSF } & 1 & $15.5 \pm 0.16$ & 92.9 \\
& 5 & 0 & 86.3 \\
\hline \multirow{2}{*}{ DTT } & 1 & $90.2 \pm 1.9$ & 101.8 \\
& 5 & $22.60 \pm 0.8$ & 97.5 \\
\hline \multirow{2}{*}{ EDTA } & 2 & $62.2 \pm 2.1$ & 95.0 \\
& 5 & $30.1 \pm 1.5$ & 81.5 \\
\hline
\end{tabular}

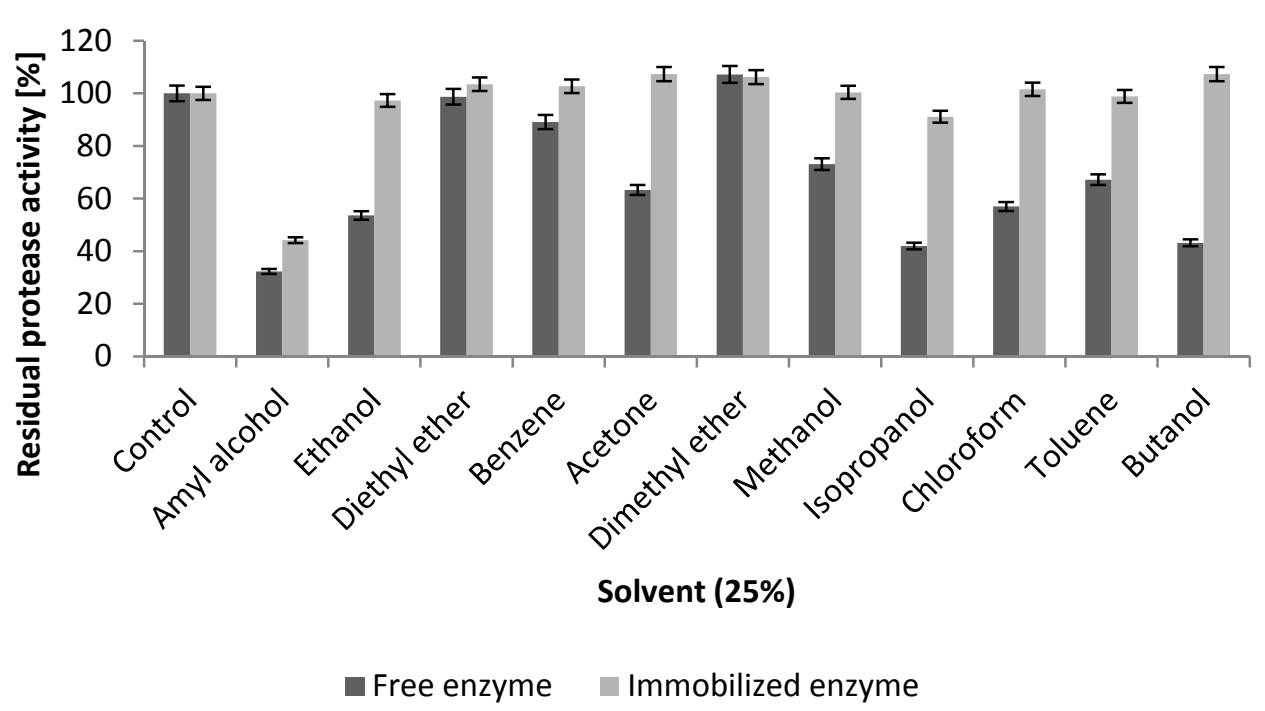

Figure 9. Effect of organic solvents on stability of free and immobilized NPST-AK15 protease.

\subsubsection{Influence of Surfactants and Commercial Laundry Detergents}

The results presented in Figure 10A show of the effect of some surfactants on the stability of free and immobilized NPST-AK15 alkaline protease. It was found that the stability of the immobilized protease exhibited higher stability in $5 \%$ lauryl glucoside, sodium dodecyl sulfate (SDS), cetyltrimethylammonium bromide (CTAB) and Triton X-100 by 9.4-, 7.5-, 3.4-, and 1.6-fold, respectively, in comparison to free enzyme. In addition, the stability of immobilized protease in Tween was improved by about 1.1-fold. Finally, to assess the compatibility and feasibility of the enzyme immobilized onto Ac-HCMSS- $\mathrm{NH}_{2}$ nanospheres as laundry detergents additive, its stability toward some commercial laundry detergents was investigated. The results illustrated in Figure 10B revealed that the immobilized protease was stable and compatible in most tested commercial laundry detergents. In comparison to free protease, the immobilized enzyme exhibited higher stability in $5 \%$ of OMO, Tide, Ariel, Bonux and X-TRA by about 5.2-, 4.9-, 4.7-, 4.5-, and 4.2-fold respectively. In addition, the stability of immobilized protease in 
5\% Ayam, Persil, and REX as improved by about 2.1-, 1.8-, and 1.8-fold, respectively. The noteworthy stability of NPST-AK15 alkaline protease covalently immobilized on activated Ac-HCMSS- $\mathrm{NH}_{2}$ nanospheres in various commercial laundry detergents suggested the effectiveness of the developed nanobiocatalyst as a candidate for detergents formulation.

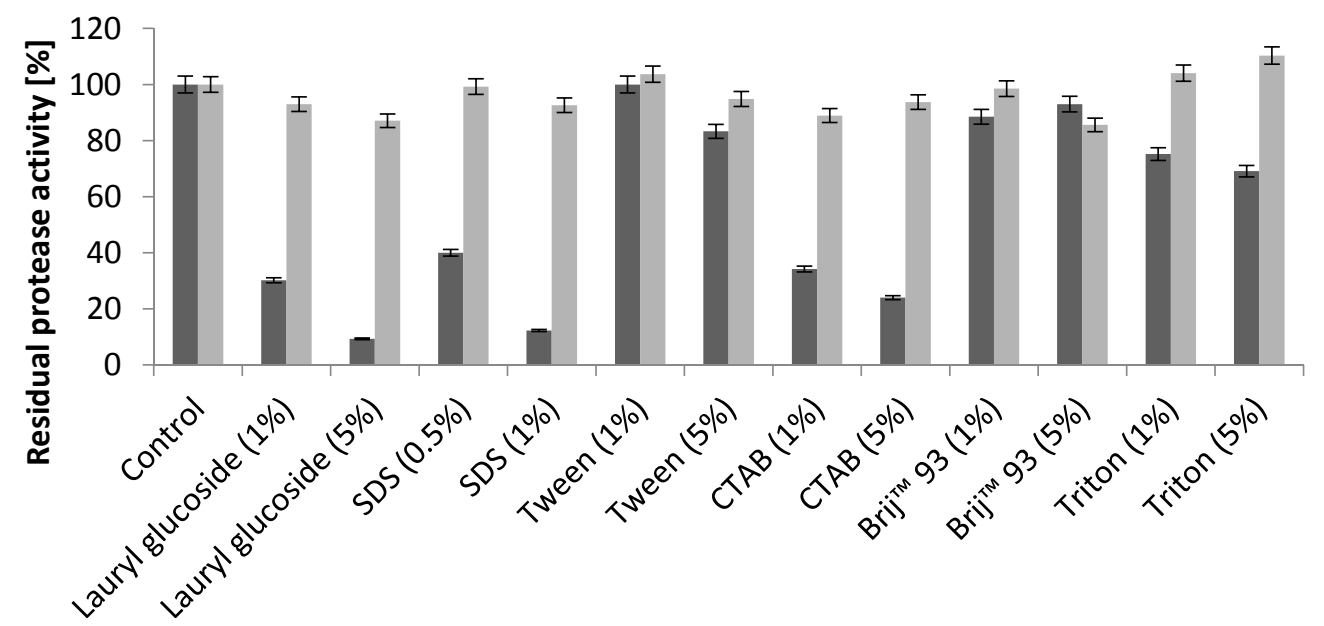

Surfactant

Free enzyme Immobilized enzyme

(A)

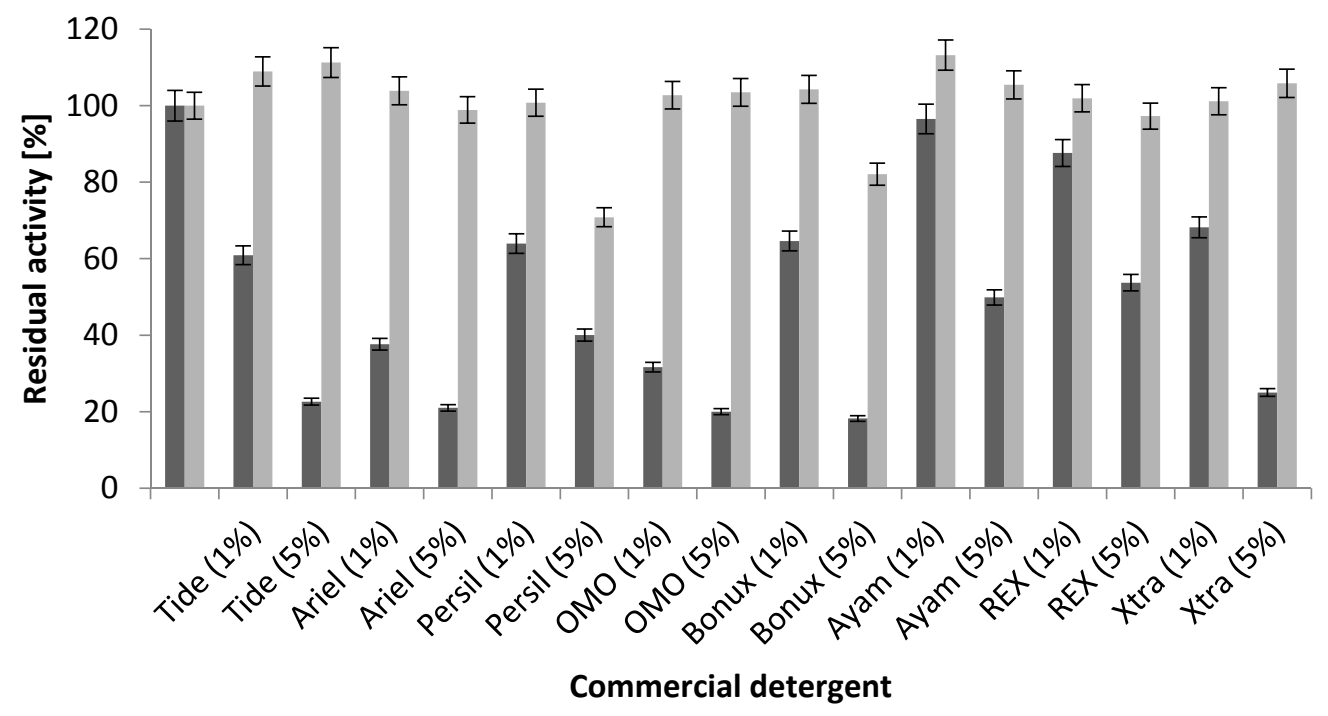

Free enzyme Immobilized enzyme

(B)

Figure 10. Effect of surfactants (A) and commercial detergents (B) on stability of free and immobilized NPST-AK15 protease stability. SDS: sodium dodecyl sulfate; CTAB: cetyltrimethylammonium bromide.

\subsubsection{Operational Stability of Immobilized Protease}

The operational stability of immobilized biocatalysts is considered as one of the most important feature that affects their applications in various bioprocesses. Generally, enzyme leakage from the carriers and enzyme inactivation represent one of the main obstacles for immobilized enzyme applications particularly 
in repeated batch and continuous process [33]. The reuse of NPST-AK15 protease immobilized onto Ac-HCMSS- $\mathrm{NH}_{2}$ nanospheres was studied in several batches for substrate hydrolysis that performed at $40{ }^{\circ} \mathrm{C}$ and $\mathrm{pH} 11$. The results indicated that after reutilizations for ten and twelve repeated cycles, the immobilized protease could retain up $65.3 \%$ and $55.6 \%$ of its initial activity, respectively, revealing a good operational stability of the developed nanobiocatalyst (Figure 11). The operational stability of immobilized biocatalyst is an essential factor for cost-effective application of immobilized enzyme system and development of novel biotechnology.

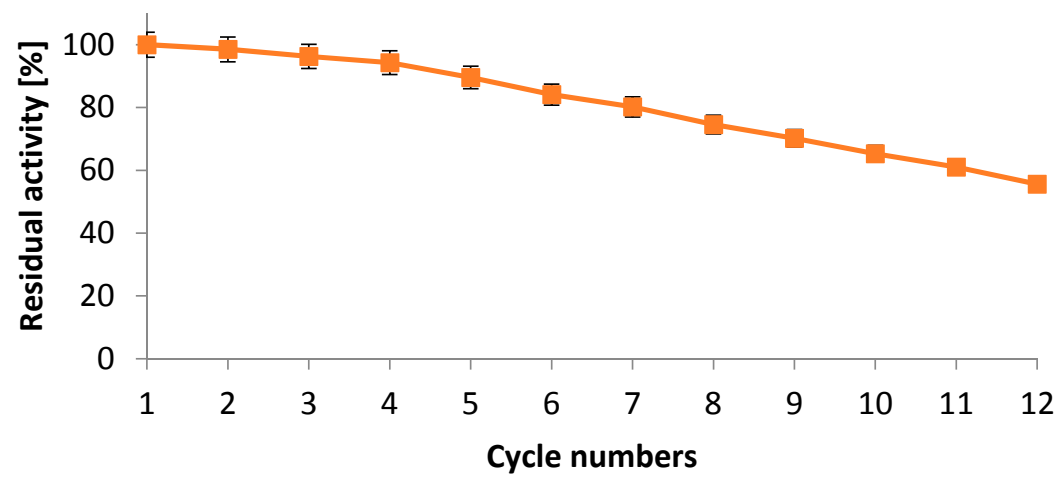

Figure 11. Reusability of NPST-AK15 protease immobilized within hollow core-mesoporous shell silica $\left(\mathrm{HCMSS}-\mathrm{NH}_{2}\right)$ nanospheres.

\section{Experimental Section}

All chemicals were of the analytical grade and, unless specified, obtained from Sigma Chemical Co. (St. Louis, MO, USA).

\subsection{Alkaline Protease Production and Purification}

Alkaliphilic alkaline protease producing Bacillus sp. strain NPST-AK15 was previously isolated from Wadi El-Natrun valley hypersaline soda lakes (Wadi El-Natrun, Egypt) [16,17]. The enzyme production was previously optimized [16] and the alkaline protease was purified and characterized [17]. The enzyme production was carried out in production medium of following composition (pH 10.5): yeast extract $(7.5 \mathrm{~g} / \mathrm{L})$, fructose $(20 \mathrm{~g} / \mathrm{L}), \mathrm{K}_{2} \mathrm{HPO}_{4}(1.0 \mathrm{~g} / \mathrm{L}), \mathrm{Mg}_{2} \mathrm{SO}_{4} \cdot 7 \mathrm{H}_{2} \mathrm{O}(0.2 \mathrm{~g} / \mathrm{L}), \mathrm{NaCl}(50 \mathrm{~g} / \mathrm{L})$, and $\mathrm{Na}_{2} \mathrm{CO}_{3}(10 \mathrm{~g} / \mathrm{L})$. An overnight culture grown at $40{ }^{\circ} \mathrm{C}$ and $150 \mathrm{rpm}$ was inoculated into $500-\mathrm{mL}$ Erlenmeyer flasks containing $100 \mathrm{~mL}$ of the production medium and incubated for about $36 \mathrm{~h}$ at $40{ }^{\circ} \mathrm{C}$. After the incubation period, cell-free supernatant was recovered by centrifugation at 10,000 rpm for $10 \mathrm{~min}$ at $4{ }^{\circ} \mathrm{C}$ and assayed for protease activity and protein content. Thereafter, NPST-AK15 protease was purified from cell-free supernatant by combination of ammonium sulfate precipitation and anion exchange column chromatography as we described in previous work [17].

\subsection{Fabrication of Hollow Core-Mesoporous Shell Silica Nanospheres}

\subsubsection{Amino-Functionalized Hollow Core-Mesoporous Shell Silica Nanospheres}

Amino-functionalized hollow core-mesoporous shell silica (HCMSS- $\mathrm{NH}_{2}$ ) nanospheres were synthesized according to previously reported methods with some modifications [34,35]. Briefly, $4 \mathrm{~mL}$ $0.1 \mathrm{M} \mathrm{HCl}$ was added to $35 \mathrm{~mL}$ of $N$-lauroylsarcosine sodium solution $(1 \mathrm{mM})$ prepared in deionized water, stirred for $1 \mathrm{~h}$ and then $0.1 \mathrm{~mL}$ of 3-aminopropyltrimethoxysilane (APMS) was added to the solution with further stirring for $10 \mathrm{~min}$. Thereafter $1.5 \mathrm{~mL}$ of tetraethyl orthosilicate (TEOS) was added to the reaction, stirred for $10 \mathrm{~min}$, subjected to ultrasonic waves for $4 \mathrm{~min}$ at $750 \mathrm{~W}$, and $20 \mathrm{KHz}$ (Sonic vibro cell, Connecticut, CT, USA), and then kept to relax for $1 \mathrm{~h}$. The mixture was heated for $18 \mathrm{~h}$ at $80^{\circ} \mathrm{C}$ and the obtained solid materials was collected by centrifugation, washed with deionized 
water and dried for $12 \mathrm{~h}$ at $60^{\circ} \mathrm{C}$. The template was removed by acid extraction to keep the hollow core-mesoporous shell silica spheres functionalized with the amino moieties. For removal of anionic surfactant, the final material was suspended in $100 \mathrm{~mL}$ of ammonium acetate solution (8\%) prepared in ethanol: $\mathrm{H}_{2} \mathrm{O}(4: 1)$ and refluxed for $12 \mathrm{~h}$ at $90{ }^{\circ} \mathrm{C}$. In order to remove amino groups from the formed hollow core-mesoporous shell silica spheres (HCMSS- $\mathrm{NH}_{2}$ ) to convert it to non-functionalized form, HCMSS- $\mathrm{NH}_{2}$ were calcined for $6 \mathrm{~h}$ in air stream at $550{ }^{\circ} \mathrm{C}$ to give HCMSS nanospheres.

\subsubsection{Hydrophobic Ethane-Functionalized Hollow Core-Mesoporous Shell Silica Nanospheres}

Ethane-functionalized hollow core-mesoporous shell silica (HCMSS- $\mathrm{C}_{2} \mathrm{H}_{5}$ ) nanospheres were prepared using post-synthesis functionalization approach according to the method of Brunel [36]. Briefly, $1 \mathrm{~mL}$ of 1,2-bis(trimethoxysilyl)ethane (BTME) was added to suspensions of freshly evacuated HCMSS dispersed in toluene $(2 \mathrm{~g} / 34 \mathrm{~mL})$, and heated at $120^{\circ} \mathrm{C}$ with stirring for $3 \mathrm{~h}$. The solid materials were collected by filtration and washed twice with a diethyl ether-dichloromethane mixture (1:1).

\subsection{Characterization of the Synthesized Mesoporous Silica Based Nanospheres}

A JEOL JSM-2100F electron microscope (Tokyo, Japan) operated at $200 \mathrm{kV}$ was used to obtain Transmission electron microscopy (TEM) images of the synthesized nanomaterials. A Quantachrome NOVA 4200 analyzer (Boynton Beach, FL, USA) was used for measurement of Nitrogen sorption isotherms at $77 \mathrm{~K}$ for various nanospheres, which were degassed in a vacuum for $18 \mathrm{~h}$ at $200{ }^{\circ} \mathrm{C}$ before the measurements. The specific surface area of the nanospheres was calculated using the Brunauer-Emmett-Teller (BET) method at relative pressure range of 0.02-0.20. The pore volumes and size distributions of different silica nanospheres were derived from the adsorption branches of isotherms using the Barrett-Joyner-Halenda $(\mathrm{BJH})$ model. In addition, the total pore volumes $\left(V_{\mathrm{t}}\right)$ were calculated from the adsorbed amount at a relative pressure $\left(\mathrm{P} / \mathrm{P}_{0}\right)$ of 0.995 . Finally, Bruker Vertex-80 spectrometer (Bruker, Massachusetts, MA, USA) was used for recording Fourier transform infrared (FT-IR) spectra.

\subsection{Alkaline Protease Immobilization}

\subsubsection{Physical Adsorption}

NPST-AK15 protease immobilization by physical adsorption was carried using HCMSS-non, HCMSS- $\mathrm{C}_{2} \mathrm{H}_{5}$ and HCMSS- $\mathrm{NH}_{2}$ according to Ibrahim et al. [37]. Briefly, $50 \mathrm{mg}$ of carriers were dispersed in $1 \mathrm{~mL}$ of glycine buffer $(50 \mathrm{mM}, \mathrm{pH}$ 8) that contained the purified NPST-AK15 protease and the suspensions were kept for overnight at $4{ }^{\circ} \mathrm{C}$ with gentle shaking. The HCMSS-enzyme nanoparticles were recovered by centrifugation for $10 \mathrm{~min}$ at 10,000 rpm, and washed twice with glycine buffer to remove any unbound enzyme. The wash solution was collected for protein content and protease activity measurement.

\subsubsection{Covalent Attachment}

Alkaline protease was covalently immobilized onto amino-functionalized hollow core-mesoporous shell silica (HCMSS- $\mathrm{NH}_{2}$ ) nanospheres according to [38] with some modifications. The matrix was first activated by glutaraldehyde $\left(\mathrm{OCHCH}_{2} \mathrm{CH}_{2} \mathrm{CHO}\right)$ as bifunctional cross linking agent and then conjugation of NPST-AK15 protease to the activated nanospheres. Briefly, $50 \mathrm{mg}$ of the HCMSS- $\mathrm{NH}_{2}$ nanospheres were dispersed in $5 \mathrm{~mL}$ of glutaraldehyde solution $(5 \%, v / v)$, prepared in deionized water and stirred for $2 \mathrm{~h}$ at room temperature. The activated matrix (Ac-HCMSS- $\mathrm{NH}_{2}$ ) was recovered from the suspension by centrifugation, and washed with large amounts of deionized water to remove any excess glutaraldehyde. Then, the Ac-HCMSS- $\mathrm{NH}_{2}$ nanopartciles $(50 \mathrm{mg})$ was suspended in $1 \mathrm{~mL}$ of glycine buffer $\left(50 \mathrm{mM}, \mathrm{pH}\right.$ 8) containing the enzyme and maintained overnight at $4{ }^{\circ} \mathrm{C}$ with gentle shaking. The Ac-HCMSS- $\mathrm{NH}_{2}$-protease nanospheres were recovered by centrifugation at 
$10,000 \mathrm{rpm}$ for $10 \mathrm{~min}$ and washed twice with the same buffer to remove any unbound enzyme. The wash solution was collected for protease activity protein content determination.

\subsection{Assay of Alkaline Protease Activity}

The catalytic activity of soluble and immobilized NPST-AK15 protease was determined using casein as a substrate according to previous method reported with some modifications [23]. A $1.0 \mathrm{~mL}$ of casein solution prepared in glycine buffer $(50 \mathrm{mM}, \mathrm{pH} 10.0)$ was pre-incubated for $5 \mathrm{~min}$ at $50^{\circ} \mathrm{C}$, then $1.0 \mathrm{~mL}$ of diluted free protease or $1.0 \mathrm{~mL}$ glycine buffer containing $50 \mathrm{mg}$ of immobilized enzyme was added and the reaction mixtures were incubated min at $50{ }^{\circ} \mathrm{C}$ for 20 . Thereafter, the enzymatic reaction was terminated by addition of $1 \mathrm{~mL}$ of $10 \%(w / v)$ of trichloroacetic acid (TCA). The mixture was kept at room temperature for $20 \mathrm{~min}$ and centrifuged at 10,000 rpm for $10 \mathrm{~min}$ to recover the precipitated materials. Lowry method was used to estimate the soluble materials in the mixture supernatant using tyrosine as a standard [39]. One unit of protease activity was defined as amount of enzyme required to liberate $1 \mu \mathrm{g}$ of tyrosine/min under the experimental assay conditions. Bradford method was used to measure the protein by using bovine serum albumin (BSA) as a standard protein [40].

\subsection{Properties of Immobilized Protease}

\subsubsection{Influence of Temperature on Protease Activity and Stability}

The optimum temperature of catalytic activity for soluble and immobilized NPST-AK15 protease were determined by measuring the enzyme activity at various temperatures ranged from $30-70{ }^{\circ} \mathrm{C}$ under standard assay conditions. The relative activities were calculated as percentage (\%) of maximum enzyme activity and the values were plotted against the respective temperature. The thermal stability of both free and immobilized protease was investigated by calculating the residual activity after incubation of enzymes at various temperatures $\left(40-60^{\circ} \mathrm{C}\right)$ for different incubation times (20-120 min). The activity of untreated protease was taken as control (\%).

\subsubsection{Influence of $\mathrm{pH}$ on Protease Activity}

The effect of $\mathrm{pH}$ on the catalytic activity of both soluble and immobilized NPST-AK15 protease was investigated by assaying the enzyme activity at different $\mathrm{pH}$ and appropriate buffers ( $50 \mathrm{mM}$ ), such as sodium acetate ( $\mathrm{pH} 5.0$ and 6.0), Tris- $\mathrm{HCl}$ ( $\mathrm{pH} 7.0$ and 8.0), glycine- $\mathrm{NaOH}$ buffer ( $\mathrm{pH}$ range 9.0-10.5) and carbonate-bicarbonate buffer ( $\mathrm{pH} 11.0-13.0)$. The substrate solution (1\% casein) was prepared in the respective $\mathrm{pH}$ buffers and the enzyme preparations (soluble and immobilized) were incubated for $20 \mathrm{~min}$ at the optimum temperature of enzyme activity. The relative activities as percentage of maximum activity were calculated and plotted against the respective $\mathrm{pH}$.

\subsubsection{Influence of Solvents and Inhibitors}

The effects of several enzyme inhibitors on the activity of free and immobilized proteases were studied. The free and immobilized protease was pre-incubated with each inhibitor at final concentrations of 1.0 or $5.0 \mathrm{mM}$ for $30 \mathrm{~min}$ at room temperature, and the residual protease activities were determined under the standard assay conditions. The tested inhibitors included ethylene diaminetetraacetic acid (EDTA), $\beta$-mercaptoethanol ( $\beta$-ME), phenylmethanesulfonyl fluoride (PMSF), and dithiothreitol (DTT). For investigation of the stability of free NPST-AK15 protease in the presence of organic solvents, the enzyme samples were pre-treated in various organic solvents (isopropanol, ethanol, methanol, dimethyl ether, diethyl ether, benzene, toluene, chloroform, acetone, butanol, and amyl alcohol) at final concentrations of $25 \%(v / v)$ for $1 \mathrm{~h}$ at $40{ }^{\circ} \mathrm{C}$. Thereafter, the residual protease activities were measured. The protease activity assayed in absence of inhibitor or solvents was used as a control (\%). 


\subsubsection{Influence of Surfactants and Commercial Detergents}

The stability of soluble and immobilized NPST-AK15 protease was further investigated in the presence of several surfactants such as lauryl glucoside, sodium dodecyl sulfate (SDS), Tween 80, cetyltrimethylammonium bromide (CTAB), Brij ${ }^{\circledR} 93$ and Triton $\mathrm{X}-100$. The free and immobilized enzyme was pre-incubated with various surfactants at final concentrations of $1.0 \%$ and $5.0 \%$ for $1 \mathrm{~h}$ at $40{ }^{\circ} \mathrm{C}$, and then the residual enzyme activities were determined. Furthermore, in order to assess the compatibility and feasibility of the immobilized proteases as laundry detergent additives, the enzyme was mixed with various commercial laundry detergent solution including Persil, Ariel, Tide, Bonux, X-TRA, REX, OMO, and Ayam prepared in tap water, with final concentrations of $1 \%(w / v)$ and incubated for $24 \mathrm{~h}$ at room temperature. The endogenous proteases in the commercial laundry detergents were inactivated by heating the diluted detergents for $10 \mathrm{~min}$ in a boiling water bath before the addition of the NPST-AK15 protease. The protease activity measured in the absence of any detergents or surfactants was used as a control.

\subsubsection{Determination of Kinetic Parameters}

For estimation of the maximum reaction rate $\left(V_{\max }\right)$ and the Michaelis-Menten constant $\left(K_{\mathrm{m}}\right)$ of free and immobilized protease, the activity assay was performed using different casein concentrations from 0.1 to $10 \mathrm{mg} / \mathrm{mL}$ in $50 \mathrm{mM}$ gylcine buffer at their optimum $\mathrm{pH}$ and temperature for soluble and immobilized enzyme. The activity assays were performed as stated above, and then $K_{\mathrm{m}}$ and $V_{\text {max }}$ were determined using Lineweaver-Burk plot [41]. In addition, the value of the turnover number $\left(k_{\text {cat }}\right)$ which defined as the maximum number of chemical conversions of substrate molecules per second that a single catalytic site will execute for a given enzyme concentration, was calculated from the equation: $k_{\text {cat }}=V_{\max } /[\mathrm{E}]$, where [E] is the enzyme molar concentration in the reaction mixture and $V_{\max }$ is the maximal reaction rate. All calculated parameters were the mean of triplicate determinations from three independent assays.

\subsubsection{Reusability of the Immobilized NPST-AK15 Protease}

For investigation of the reusability of immobilized NPST-AK15 protease, the immobilized enzyme was reused for 12 consecutive cycles using $2 \mathrm{~mL}$ of the standard reaction mixture. The reaction mixture that contained the immobilized enzyme was incubated in a shaking water bath (120 rpm) at $40{ }^{\circ} \mathrm{C}$ for $20 \mathrm{~min}$. At the end of each cycle, the immobilized protease was removed from the reaction medium, washed with glycine buffer and was used to start a cycle using fresh substrate solution.

\subsection{Statistical Analysis}

Experimental results were given as mean value \pm SD of three parallel measurements. All statistical analyses were conducted using Microsoft Excel.

\section{Conclusions}

Alkaline protease from Bacillus sp. NPST-AK15 was immobilized onto functionalized and non-functionalized HCMSS nanospheres by physical and covalent immobilization. However, NPST-AK15 protease immobilization by covalent attachment onto activated amino-functionalized hollow core-mesoporous shell silica (Ac-HCMSS-NH $_{2}$ ) nanospheres, through cross linking agent, was more effective showing much higher immobilization yield and loading efficiency in comparison with the physical adsorption approach. The immobilized NPST-AK15 protease exhibited significant improvement of thermal and $\mathrm{pH}$ stability in respect to free enzyme. Moreover, NPST-AK15 protease immobilization led to enzyme protection against several inhibitors. Interestingly, the immobilized protease exhibited significant improvement of protease stability in a variety of organic solvents, surfactants and commercial laundry detergents. In addition, the immobilized enzyme exhibited good operational stability up to twelve 
reaction batches. The developed immobilized alkaline protease is a promising nanobiocatalyst for laundry detergent formulations and various applications for alkaline protease.

Acknowledgments: This project was funded by the National Plan for Science, Technology and Innovation (MAARIFAH), King Abdulaziz City for Science and Technology, Kingdom of Saudi Arabia, Award Number (12 BIO2899-02).

Author Contributions: The work objectives were selected and designed by Abdelnasser Salah Shebl Ibrahim; The results analysis, interpretation, discussion, manuscript preparation and submission were carried out by Abdelnasser Salah Shebl Ibrahim; Ahmed M. El-Toni was responsible for synthesis and characterization of the nanostructured materials, manuscript discussion and preparation; Abdelnasser Salah Shebl Ibrahim, Mohamed A. El-Tayeb and Yahya B. Elbadawi carried out the experimental work related to microbiology and biochemistry; Ali A. Al-Salamah contributed in the data analysis, discussion, and provided administrative support; Garabed Antranikian consulted and guided the project; Khalid S. Almaary contributed in discussion, revision and editing of the manuscript. All authors have read and approved the final manuscript.

Conflicts of Interest: The authors declare no conflict of interest.

\section{References}

1. Jain, D.; Pancha, I.; Mishra, S.K.; Shrivastav, A.; Mishra, S. Purification and characterization of haloalkaline thermoactive, solvent stable and SDS-induced protease from Bacillus sp.: A potential additive for laundry detergents. Bioresour. Technol. 2012, 115, 228-236. [CrossRef] [PubMed]

2. Soozanipour, A.; Taheri-Kafrani, A.; Isfahani, A.L. Covalent attachment of xylanase on functionalized magnetic nanoparticles and determination of its activity and stability. Chem. Eng. J. 2015, 270, 235-243. [CrossRef]

3. Bouacem, K.; Bouanane-Darenfed, A.; Laribi-Habchi, H.; ben Elhoul, M.; Hmida-Sayari, A.; Hacene, H.; Ollivier, B.; Fardeau, M.L.; Jaouadi, B.; Bejar, S. Biochemical characterization of a detergent stable serine alkalineprotease from Caldicoprobacter guelmensis. Int. J. Biol. Macromol. 2015, 81, 299-307. [CrossRef] [PubMed]

4. Ben Elhoul, M.; Jaouadi, N.Z.; Rekik, H.; Bejar, W.; Touioui, S.B.; Hmidi, M.; Badis, A.; Bejar, S.; Jaouadi, B. A novel detergent-stable solvent-tolerant serine thiol alkaline protease from Streptomyces koyangensis TN650. Int. J. Biol. Macromol. 2015, 79, 871-882. [CrossRef] [PubMed]

5. Patil, U.; Chaudhari, A. Purification and characterizationofsolvent-tolerant, thermostable, alkaline metalloprotease from alkalophilic Pseudomonas aeruginosa MTCC 7926. J. Chem. Technol. Biotechnol. 2009, 84, 1255-1262. [CrossRef]

6. Mokashe, N.; Chaudhari, A.; Patil, U. Optimal production and characterization of alkaline protease from newly isolated halotolerant Jeotgalicoccus sp. Biocatal. Agric. Biotechnol. 2015, 4, 235-243. [CrossRef]

7. Gupta, A.; Khare, S.K. Enhanced production and characterization of a solvent stable protease from solvent tolerant Pseudomonas aeruginosa PseA. Enzym. Microb. Technol. 2007, 42, 11-16. [CrossRef]

8. Alqueres, S.C.; Almeida, R.V.; Clementino, M.M.; Vieira, R.P.; Almeida, W.I.; Cardoso, A.M.; Martins, O.B. Exploring the biotechnological applications in the archaeal domain. Braz. J. Microbiol. 2007, 38, 398-405. [CrossRef]

9. Mateo, C.; Palomo, J.M.; Fernandez-Lorente, G.; Guisan, J.M.; Fernandez-Lafuente, R. Improvement of enzyme activity, stability and selectivity via immobilization techniques. Enzym. Microb. Technol. 2007, 40, 1451-1463. [CrossRef]

10. Kumar, A.G.; Swarnalatha, S.; Kamatchia, P.; Sekaran, G. Immobilization of high catalytic acid protease on functionalized mesoporous activated carbon particles. Biochem. Eng. J. 2009, 43, 185-190. [CrossRef]

11. Wang, P. Nanoscale biocatalyst systems. Curr. Opin. Biotechnol. 2006, 17, 574-579. [CrossRef] [PubMed]

12. Lee, C.H.; Lin, T.S.; Mou, C.Y. Mesoporous materials for encapsulating enzymes. Nano Today 2009, 4, $165-179$. [CrossRef]

13. Fan, J.; Lei, J.; Wang, L.M.; Yu, C.Z.; Tu, B.; Zhao, D.Y. Rapid and highcapacity immobilization of enzymes based on mesoporous silicas with controlled morphologies. Chem. Commun. 2003, 17, 2140-2141. [CrossRef]

14. Blasi, L.; Longo, L.; Vasapollo, G.; Cingolani, R.; Rinaldi, R.; Rizzello, T.; Acierno, R.; Maffia, M. Characterization of glutamate dehydrogenase immobilization on silica surface by atomic force microscopy and kinetic analyses. Enzym. Microb. Technol. 2005, 36, 818-823. [CrossRef]

15. Xiao, Q.G.; Tao, X.; Zoub, H.K.; Chen, J.F. Comparative study of solid silica nanoparticles and hollow silica nanoparticles for the immobilization of lysozyme. Chem. Eng. J. 2008, 137, 38-44. [CrossRef]

16. Ibrahim, A.S.; Al-Salamah, A.A.; El-Badawi, Y.B.; El-Tayeb, M.A.; Ibrahim, S.S. NPST-AK15 isolated from hyper saline soda lakes. Electron. J. Biotechnol. 2015, 18, 236-243. [CrossRef] 
17. Ibrahim, A.S.; Al-Salamah, A.A.; El-Badawi, Y.B.; El-Tayeb, M.A.; Antranikian, G. Detergent-, solvent- and salt-compatible thermoactive alkaline serine protease from halotolerant alkaliphilic Bacillus sp. NPST-AK15: Purification and characterization. Extremophiles 2015, 19, 961-971. [CrossRef] [PubMed]

18. Nikolić, M.P.; Giannakopoulos, K.P.; Bokorov, M.; Srdić, V.V. Effect of surface functionalization on synthesis of mesoporous silica core/shell particles. Microporous Mesoporous Mater. 2012, 155, 8-13. [CrossRef]

19. Yamaura, M.; Camilo, R.L.; Sampaio, L.C.; Macedo, M.A.; Nakamura, M.; Toma, H.E. Preparation and characterization of (3-aminopropyl)triethoxysilane-coated magnetite nanoparticles. J. Magn. Magn. Mater. 2004, 279, 210-217. [CrossRef]

20. Zhang, L.; Liu, J.; Yang, J.; Yang, Q.; Li, C. Direct synthesis of highly ordered amine functionalized mesoporous ethane-silicas. Microporous Mesoporous Mater. 2008, 109, 172-183. [CrossRef]

21. Sulek, F.; Knez, Z.; Habulin, M. Immobilization of cholesterol oxidase to finely dispersed silica coated maghemite nanoparticles based magnetic fluid. Appl. Surf. Sci. 2010, 256, 4596-4600. [CrossRef]

22. Lei, C.; Soares, T.A.; Shin, Y.; Liu, J.; Ackerman, E.J. Enzyme specific activity in functionalized nanoporous supports. Nanotechnology 2008, 19, 125102-125111. [PubMed]

23. Jin, X.; Li, J.; Huang, P.; Dong, X.; Guo, L.; Yang, L.; Cao, Y.; Wei, F.; Zhao, Y.; Chen, H. Immobilized protease on the magnetic nanoparticles used for the hydrolysis of rapeseed meals. J. Magn. Magn. Mater. 2010, 322, 2031-2037. [CrossRef]

24. Kharrat, N.; Ben-Ali, Y.; Marzouk, S.; Gargouria, Y.T.; Karra-Chaabounia, M. Immobilization of Rhizopus oryzae lipase on silica aerogels by adsorption: Comparison with the free enzyme. Process Biochem. 2011, 46, 1083-1089. [CrossRef]

25. Huang, J.; Liu, H.; Zhang, P.; Zhang, P.; Li, M.; Ding, L. Immobilization of cholesterol oxidase on magnetic fluorescent core-shell-structured nanoparticles. Mater. Sci. Eng. C 2015, 57, 31-37.

26. Kim, K.D.; Kim, S.S.; Choa, Y.H.; Kim, H.T. Formation and surfacemodification of $\mathrm{Fe}_{3} \mathrm{O}_{4}$ nanoparticles by co-precipitation and sol-gel method. J. Ind. Eng. Chem. 2007, 13, 1137-1141.

27. Cui, Y.; Li, Y.; Yang, Y.; Liu, X.; Lei, L.; Zhou, L. Facile synthesis of aminosilane modified superparamagnetic $\mathrm{Fe}_{3} \mathrm{O}_{4}$ nanoparticles and application for lipase immobilization. J. Biotechnol. 2010, 150, 171-174. [CrossRef] [PubMed]

28. Su, R.; Shi, P.; Zhu, M.; Hong, F.; Li, D. Studies on the properties of graphene oxide-alkaline protease bio-composites. Bioresour. Technol. 2012, 115, 136-140. [CrossRef] [PubMed]

29. Ranjbakhsh, E.; Bordbar, A.K.; Abbasi, M.; Khosropour, A.R.; Shams, E. Enhancement of stability and catalytic activity of immobilized lipase on silica-coated modified magnetite nanoparticles. Chem. Eng. J. 2012, 179, 272-276. [CrossRef]

30. Ansari, S.A.; Husain, Q. Potential applications of enzymes immobilized on/in nano materials: A review. Biotechnol. Adv. 2011, 30, 512-523. [CrossRef] [PubMed]

31. Kapoor, M.; Kuhad, R.C. Immobilization of xylanase from Bacillus pumilus strain MK001 and its application in production of xylo-oligosaccharides. Appl. Biochem. Biotechnol. 2007, 142, 125-138. [CrossRef] [PubMed]

32. Jellouli, K.; Ghorbel-Bellaaj, O.; Ayed, H.; Manni, L.; Agrebi, R.; Nasri, M. Alkaline-protease from Bacillus licheniformis MP1: Purification, characterization and potential application as a detergents additive and for shrimp waste deproteinization. Process Biochem. 2011, 46, 1248-1256. [CrossRef]

33. Corici, L.; Frissen, A.; Zoelen, D.; Eggen, I.; Peter, F.; Davidescu, C.; Boeriu, C. Sol-gel immobilization of Alcalase from Bacillus licheniformis for application in the synthesis of C-terminal peptide amides. J. Mol. Catal. B Enzym. 2011, 73, 90-97. [CrossRef]

34. Zheng, H.; Gao, C.; Che, S. Amino and quaternary ammonium group functionalized mesoporous silica: An efficient ion-exchange method to remove anionic surfactant from AMS. Microporous Mesoporous Mater. 2008, 116, 299-307. [CrossRef]

35. El-Toni, A.M.; Habila, M.A.; Ibrahim, M.A.; Labis, J.P.; al Othman, Z.A. Simple and facile synthesis of amino functionalized hollow core-mesoporous shell silica spheres using anionic surfactant for $\mathrm{Pb}(\mathrm{II}), \mathrm{Cd}(\mathrm{II})$, and Zn(II) adsorption and recovery. Chem. Eng. J. 2014, 251, 441-451. [CrossRef]

36. Brunel, D. Functionalized micelle-templated silicas (MTS) and their use as catalysts for fine chemicals. Microporous Mesoporous Mater. 1999, 27, 329-344. [CrossRef]

37. Ibrahim, A.S.; Al-Salamah, A.A.; El-Toni, A.M.; El-Tayeb, M.A.; Elbadawi, Y.B. Immobilization of cyclodextrin glucanotransferase on aminopropyl-functionalized silica-coated superparamagnetic nanoparticles. Electron. J. Biotechnol. 2013, 16, 1-8. [CrossRef] 
38. Shi, B.; Wang, Y.; Ren, J.; Liu, X.; Zhang, Y.; Guo, Y. Superparamagnetic aminopropyl functionalized silica core-shell microspheres as magnetically separable carriers for immobilization of penicillin G acylase. J. Mol. Catal. B Enzym. 2010, 63, 50-56. [CrossRef]

39. Lowry, O.H.; Rosebrough, N.J.; Farr, A.L.; Randall, J. Protein measurement with the Folin phenol reagent. J. Biol. Chem. 1951, 193, 265-275. [PubMed]

40. Bradford, M.M. A rapid and sensitive method for the quantitation of microgram quantities of protein utilizing the principle of protein-dye binding. Anal. Biochem. 1976, 72, 248-254. [CrossRef]

41. Mathews, C.K.; Holde, K.E.; Holde, K.F. Dynamic of Life: Catalysis and Control of Biochemical Reactions. In Biochemistry, 4th ed.; Prentice Hall: New Jersey, NJ, USA, 2012.

(C) 2016 by the authors; licensee MDPI, Basel, Switzerland. This article is an open access article distributed under the terms and conditions of the Creative Commons by Attribution (CC-BY) license (http://creativecommons.org/licenses/by/4.0/). 